J. Lake Sci. (湖泊科学), 2019, 31(4): 998-1011

DOI 10. 18307/2019. 0406

(C) 2019 by Journal of Lake Sciences

\title{
济南市不同区域水生生物与水环境因子的响应关系
}

\author{
刘麟菲 ${ }^{1,2}$,徐宗学 ${ }^{1,2 * *}$, 殷旭旺 ${ }^{3}$, 李福林 ${ }^{4}$, 王 泊 $^{3}$ \\ (1: 北京师范大学水科学研究院, 北京 100875) \\ ( 2 : 城市水循环与海绵城市技术北京市重点实验室, 北京 100875) \\ (3: 大连海洋大学水产与生命学院, 辽宁省水生生物学重点实验室, 大连 116023) \\ (4: 山东省水利科学研究院,济南 250013)
}

\begin{abstract}
摘 要: 水生生物与水环境因子是水生态系统中重要的组成部分, 研究水生生物与水环境因子的响应关系对制定水生态 系统修复方案具有重要意义. 于 2014 年 $5 、 8$ 和 10 月, 对济南市水生态系统进行野外采样调查. 共设 36 个采样点, 采集鱼 类、底栖动物、浮游动物和浮游植物四种生物, 并测定了 26 个水环境因子. 采用 Spearman 相关分析法、小提琴图法和圥余 分析法, 篮选主要的水环境因子, 分析济南市水生生物丰富度和主要水环境因子的分布特征, 以及两者间的相互关系. 结 果表明, 共䇥选出 6 个主要的水环境因子, 分别为流量 (Flow)、溶解氧 (DO)、栖息地质量指数 ( QHEI)、电导率 (Cond)、化 学需氧量 (COD) 和总氮 (TN). 黄河区 Flow、DO、QHEI 和水生生物丰富度均较高, 小清河区 COD、TN、Cond 和水生生物丰 富度最低. 黄河区 Cond 与鱼类丰富度呈显著相关, 城区 TN 与底栖动物丰富度呈显著相关, 小清河区 COD、DO 和 QHEI 对水生生物丰富度有显著影响, 徒骇马项河区 TN 对水生生物丰富度有显著影响. 该研究为济南市水生态修复方案的制 定提供参考,也为其他城市水生态文明建设提供一种思路.
\end{abstract}

关键词: 相关分析;圥余分析;水生生物丰富度;水环境因子;济南市

\section{Response of aquatic organism richness to physiochemical factors at different regions in Jinan City}

\author{
LIU Linfei ${ }^{1,2}$, XU Zongxue ${ }^{1,2 * *}$, YIN Xuwang ${ }^{3}$, LI Fulin ${ }^{4} \&$ WANG Mi $^{3}$ \\ (1: College of Water Sciences, Beijing Normal University, Beijing 100875, P.R.China) \\ (2: Beijing Key Laboratory of Urban Hydrological Cycle and Sponge City Technology, Beijing 100875, P.R.China) \\ (3: College of Fisheries and Life Science, Dalian Ocean University, Dalian 116023, P.R.China) \\ (4: Water Resources Research Institute of Shandong Province, Jinan 250013, P.R.China)
}

Abstract: Aquatic organisms and physiochemical factors were important components in the aquatic ecosystem. It will be benefited for understanding the health condition of aquatic ecosystem and planning restoration project by investigating the relationships between aquatic organisms and physiochemical factors. In this study, 36 sampling stations were set to investigated fish, macroinvertebrate, zooplankton and phytoplankton assemblages during May, August and October in 2014 in Jinan City, whilst, 26 physiochemical variables were tested as well. Methods of Spearman analysis, violin-plots and redundancy analysis were used to select the main physiochemical factors, exhibit the distribution of biological richness and main factors at each regions, and analyze the relationship between biological richness and main factors at each region. The results showed that six physiochemical factors including Flow, dissolved oxygen (DO), qualitative habitat evaluation index ( QHEI), COD, electrical conductivity (Cond) and total nitrogen ( TN) were selected as the main environmental factors based on the Spearman analysis. The distribution of Flow, DO, QHEI and biological richness were higher in Yellow River regions than those in other regions, and COD, TN, Cond and biological richness were the lowest in the Xiaoqing River region. Based on the Spearman analysis, Cond had a significant correlation with fish richness in Yellow River region, and TN were significant correlated with macroinvertebrate richness in urban region. The redundancy analysis showed

* 水生态文明试点科技支撑计划 (SSTWMZCJH-SD02) 资助. 2018-11-05 收稿; 2018-12-01 收修改稿. 刘麟菲 (1987 ),女,博士研究生; E-mail: liulinfei@ mail.bnu.edu.cn.

** 通信作者; E-mail: zongxuexu@ vip.sina.com. 
that TN had a significant impact on the biological richness in Tuhaimajia River region, and COD, DO and QHEI significantly affected the biological richness in Xiaoqing River region. This study could be used as reference for the management or government to design a restoration project of aquatic ecosystem in Jinan City, and provided a new way for other cities to develop the aquatic ecosystem as well.

Keywords: Correlation analysis; redundancy analysis; biological richness; physiochemical factors; Jinan City

随着人们对水生态系统环境健康状况意识的增强, 对水生态系统的监测、修复与保护的研究日益增 多 ${ }^{[1-3]}$. 水生生物和水环境因子是水生态系统中重要的组成部分, 与水生态系统健康状况息息相关, 了解和 掌握水生生物对水环境因子的响应关系, 可以更有利于制定或调整水生态系统修复和保护方案 ${ }^{[4-6]}$, 为建设 生态文明城市提供技术支持.

鱼类、底栖动物、浮游植物和浮游动物是水体中常见的水生生物 ${ }^{[7-14]}$. 这些生物在水生态系统中处于不 同的生态位和营养级, 且每个类群生物的生活习性和活动能力均有所差异, 可以较好地反映水体中不同层 次的水环境质量. 如鱼类处于水体食物链顶端且活动能力较强, 生命周期较长, 可以反映大尺度范围内水体 中环境因子对鱼类造成的长期影响 ${ }^{[15-16]}$. 王晓宁等 ${ }^{[17]}$ 对滦河流域鱼类空间异质性及环境响应关系进行研 究,发现总溶解性固体、浊度、 $\mathrm{pH}$ 、水温、底质和堤岸稳定性是影响鱼类群落分布的主要驱动因子. 底栖动物 栖居于水体底层, 具有一定的活动能力, 可以反映水体底质质量状况 ${ }^{[18]}$. 如王璐等 ${ }^{[19]}$ 对长白山源头溪流底 栖动物进行调查,发现水温、调落叶分布、流速是影响底栖动物分布的主要环境因子. 浮游植物是水体中初 级生产者, 藻类数量的多葟直接影响较高营养级生物的丰富度和数量, 且由于藻类生命周期短, 移动能力 弱,对水环境变化可迅速做出反应, 特别对营养物含量反应敏感 ${ }^{[20]}$. 蔡琨等 ${ }^{[21]}$ 研究发现, 氨氮和总磷浓度与 太湖浮游植物完整性指数具有显著相关性. 浮游动物是水生态系统中的初级消费者, 以浮游植物为食, 又是 重要经济鱼类的开口饵料, 在物质循环和能力流动中起着承上启下的作用 ${ }^{[22]}$. 吴利 等 $^{[23]}$ 研究发现, 水温、溶 解氧、流速与淮河干流浮游动物群落结构具有较强的相关性. 这些研究均表明, 水生生物对水环境质量具有 较好的指示作用,但多数研究仅用单一生物类群探索与水环境因子的响应关系,而研究同一流域内不同生 物与水环境因子的响应关系,对准确全面了解该区域水生态系统健康状况具有重要意义.

济南市是水利部批准的全国首个水生态文明建设试点城市. 作为古今中外、远近闻名的泉城, 其独特的 自然风貌和深厚的文化底蕴使济南市成为独具一格的旅游生态城市. 然而, 随着城市现代化的推进, 济南市 逐步出现水资源短缺、水污染严重、地下水超采、水生态退化等众多水生态系统健康问题, 是全国较为典型 的因人类活动的剧烈扰动使原有的优质水生态系统遭受破坏的城市. 因此, 以济南市为首个水生态文明建 设试点城市, 既可以保障济南市人民的生活质量, 又为水生态文明建设在全国其他城市的推广起到示范作 用. 本研究以济南市为研究区, 对济南市主要河流展开调查, 分析济南市各区域水生生物丰富度和水环境因 子的分布特征, 以及两者间的响应关系, 了解济南市各区域水生态系统现状以及存在的问题, 有针对性的在 各区域制定合理化修复方案, 以期为济南市水生态治理、修复和保护提供技术支持, 也为其他城市进行水生 态文明建设提供技术指导.

\section{1 材料与方法}

\section{1 采样点布设}

济南市位于我国华北平原中部, 流域面积 $8177 \mathrm{~km}^{2}$. 地势南高北低, 西高东低, 海拔高程为 $20 \sim 988 \mathrm{~m}$, 由南向北, 可划分为南部低山丘陵区、中部山前平原区和北部黄河冲积平原区 ${ }^{[24]}$. 受地势影响, 济南河流多 呈单侧树枝状, 支流一般从右岸南部汇人干流. 济南市境内有三大水系, 分别为黄河水系、小清河水系和徒 骇马䒜河水系. 其中黄河水系为黄河流域的一部分, 流经济南市的河流长度为 $172.9 \mathrm{~km}$, 集水面积为 2778 $\mathrm{km}^{2}$, 主要支流有玉符河、南大沙河、北大沙河等 10 条. 小清河水系属于淮河水系,市境内流经长度为 70.3 $\mathrm{km}$, 集水面积 $2792 \mathrm{~km}^{2}$, 主要支流有腊山河、巨野河、绣江河等. 徒骇马颊河水系属海河水系, 济南段流经长 度为 $88.5 \mathrm{~km}$, 集水面积 $2400 \mathrm{~km}^{2}$, 主要支流有徒骇河、德惠新河等 ${ }^{[25-26]}$. 以 3 个水系为基准点, 划分为黄河 区、小清河区和徒骇马颊河区 ${ }^{[26]}$. 城市中心区属于小清河区, 但由于其区域面积最小, 人口密度最大,类型 
较为特殊, 因此单独划分为一区. 共将济南市划分为黄河区 ( I )、城区 ( II )、小清河区 ( III) 和徒骇马颙河区 ( IV).

本研究于 2014 年 5、8、10 月对济南市进行了 3 次采样调查, 共设 36 个采样点, 其中, 黄河区点位 9 个, 城区点位 6 个, 小清河区点位 9 个, 徒骇马颊河区点位 12 个(图 1). 每个点位均采集鱼类、底栖动物、浮游动 物和浮游植物,并测定水环境理化因子. 具体采样点信息见表 1 .

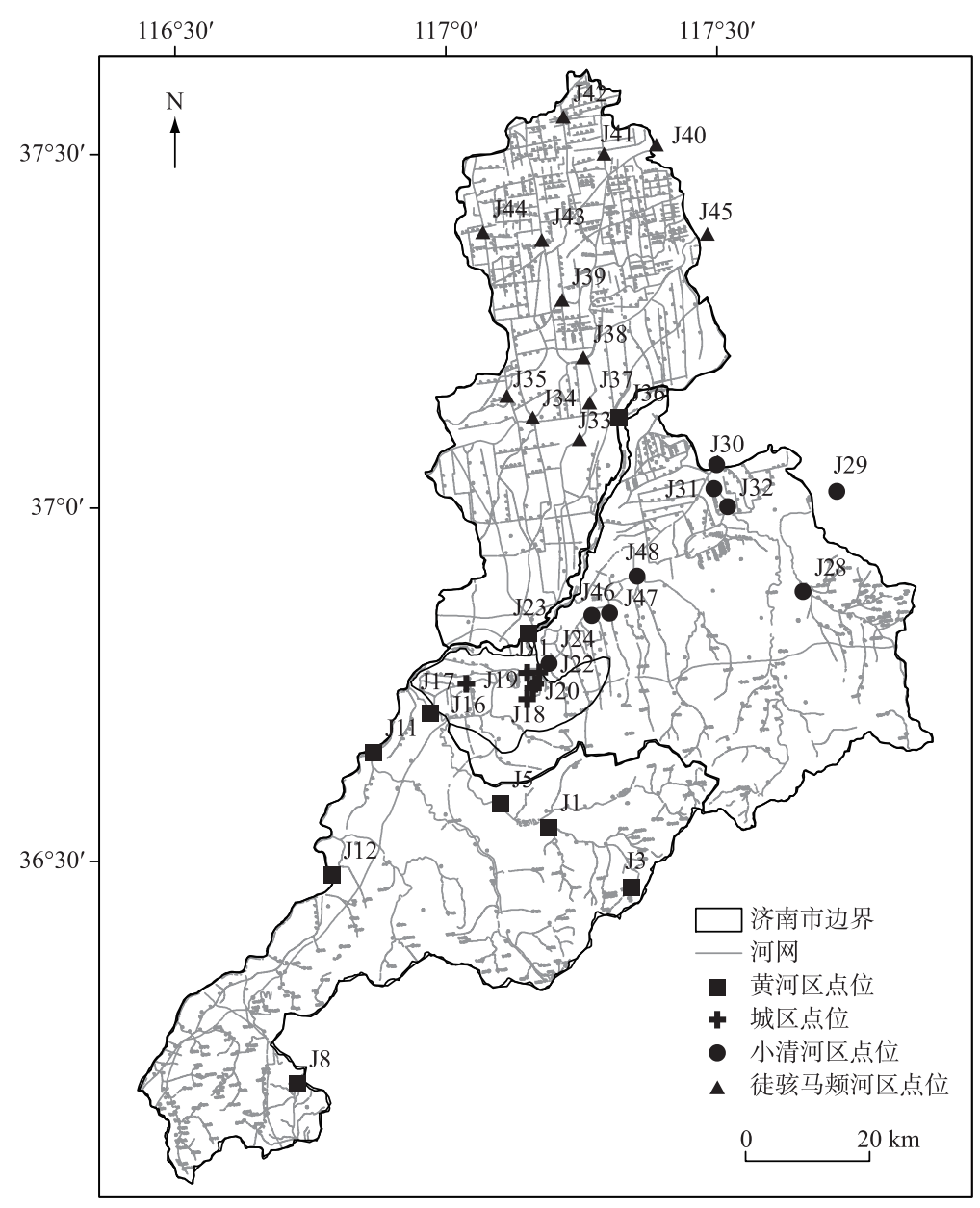

图 1 济南市各区域采样点分布

Fig. 1 Distribution of sampling sites at each ecoregion in Jinan City

\section{2 数据获取}

1.2.1 水生生物样品采集 1 ) 鱼类. 距采样点上游 $1 \mathrm{~km}$ 范围内进行鱼类样品的采集. 采集方法为电鱼法, 采 样时间为 $30 \mathrm{~min}$. 现场进行鱼类的鉴定 ${ }^{[27-29]}$ 和称重, 鉴定结束后放生. 对于不确定的种类, 用 $10 \%$ 的甲醛固 定,带回实验室进行进一步鉴定分析.

2 ) 底栖动物. 使用 $1 / 16$ 彼得森采泥器( PBS-411) 在采样点随机选取 2 处进行底栖动物的采集. 将采集 到的所有物质倒人塑料桶中, 经 60 目篮网过滤, 将网上残留物质转移到白瓷盘中, 现场挑拣底栖动物. 将挑 拣的底栖动物放人 $150 \mathrm{ml}$ 塑料广口瓶中, 用 $95 \%$ 工业酒精固定保存. 在实验室解剖镜下进行物种的 鉴定 ${ }^{[30-32]}$.

3) 浮游动物. 每个采样点采水 $50 \mathrm{~L}$, 用 $25^{\#}$ 浮游生物网 (300 目) 过滤, 将滤出的浮游动物转移到 $50 \mathrm{ml}$ 塑 
料瓶中, 定容至 $20 \mathrm{ml}$, 加人 $5 \%$ 甲醛固定. 在实验室 10 倍显微镜下进行物种鉴定 ${ }^{[33-36]}$.

4) 浮游植物. 用采水器采集河水 $2 \mathrm{~L}$, 转移到塑料瓶中, 加人 $10 \sim 15 \mathrm{ml}$ 鲁哥氏碘液固定. 在实验室静置 $48 \mathrm{~h}$ 后, 用虹吸管去除上清液, 将剩余沉淀液体转移到 $100 \mathrm{ml}$ 塑料瓶中, 定容至 $50 \mathrm{ml}$. 在 40 倍显微镜下鉴 定,物种鉴定到最小分类单元 ${ }^{[37-38]}$.

表 1 济南市各区域不同采样点基本信息

Tab.1 Basic information for different sampling sites at each ecoregion in Jinan City

\begin{tabular}{|c|c|c|c|c|c|c|}
\hline 编号 & 点位名称 & 所属区域 & 河流名称 & 土地利用方式 & 非点源污染 & 底质类型 \\
\hline $\mathrm{J} 1$ & 并渡口 & 黄河区 & 玉符河 & 林地、住宅 & 不明显 & 石块、砂砾、沙 \\
\hline $\mathrm{J} 3$ & 黄巢水库下游 & 黄河区 & 锦阳川 & 林地 & 不明显 & 石块、卵石、砂砾 \\
\hline $\mathrm{J} 5$ & 宅科 & 黄河区 & 玉符河 & 公路 & 不明显 & 碎石、细沙 \\
\hline $\mathrm{J} 8$ & 陈屯桥 & 黄河区 & 汇河 & 耕地 & 有潜在污染源 & 淤泥 \\
\hline $\mathrm{J} 11$ & 北大沙河 & 黄河区 & 北大沙河 & 林地 & 不明显 & 淤泥 \\
\hline $\mathrm{J} 12$ & 顾小庄浮桥 & 黄河区 & 黄河 & 沙地 & 不明显 & 沙 \\
\hline J16 & 睦里庄 & 黄河区 & 玉符河 & 耕地 & 有潜在污染源 & 淤泥、沙 \\
\hline $\mathrm{J} 23$ & 泺口 & 黄河区 & 黄河 & 沙地 & 不明显 & 沙 \\
\hline $\mathrm{J} 36$ & 葛店引黄闸 & 黄河区 & 黄河 & 林地 & 不明显 & 沙、砂砾、淤泥 \\
\hline $\mathrm{J} 17$ & 吴家铺 & 城区 & 小清河 & 公园 & 不明显 & 淤泥 \\
\hline $\mathrm{J} 18$ & 大明湖 & 城区 & 小清河 & 公园 & 不明显 & 淤泥 \\
\hline J19 & 跑突泉 & 城区 & & 公园 & 不明显 & 岩床 \\
\hline $\mathrm{J} 20$ & 梁府庄 & 城区 & 小清河 & 住宅 & 有潜在污染源 & 石床 \\
\hline $\mathrm{J} 21$ & 板桥 & 城区 & 小清河 & 住宅 & 有潜在污染源 & 石床 \\
\hline $\mathrm{J} 22$ & 菜市新村 & 城区 & 小清河 & 住宅 & 明显 & 石床 \\
\hline $\mathrm{J} 24$ & 黄台桥 & 小清河区 & 小清河 & 住宅 & 有潜在污染源 & 石床 \\
\hline $\mathrm{J} 28$ & 相公庄 & 小清河区 & 漯河 & 商业、住宅 & 明显 & 淤泥 \\
\hline $\mathrm{J} 29$ & 吘山闸 & 小清河区 & 杏花河 & 林地 & 不明显 & 淤泥 \\
\hline $\mathrm{J} 30$ & 五龙堂 & 小清河区 & 小清河 & 林地、耕地 & 有潜在污染源 & 淤泥、沙、砂砾 \\
\hline $\mathrm{J} 31$ & 张家林 & 小清河区 & 绣江河 & 耕地、住宅 & 有潜在污染源 & 石块、淤泥 \\
\hline $\mathrm{J} 32$ & 白云湖 & 小清河区 & 绣江河 & 耕地 & 有潜在污染源 & 黏土、淤泥 \\
\hline J46 & 龙脊河 & 小清河区 & 龙脊河 & 耕地、住宅、工业 & 有潜在污染源 & 淤泥 \\
\hline $\mathrm{J} 47$ & 石河 & 小清河区 & 石河 & 耕地、住宅、工业 & 明显 & 淤泥、砂砾、石块 \\
\hline $\mathrm{J} 48$ & 巨野河 & 小清河区 & 巨野河 & 林地、耕地 & 有潜在污染源 & 淤泥 \\
\hline $\mathrm{J} 33$ & 北田家 & 徒骇马㚘河区 & 大寺河 & 林地、耕地、工业 & 有潜在污染源 & 淤泥 \\
\hline $\mathrm{J} 34$ & 垛石街 & 徒骇马㚘河区 & 垛石河 & 林地、耕地、住宅 & 有潜在污染源 & 淤泥 \\
\hline $\mathrm{J} 35$ & 新市董家 & 徒骇马项河区 & 临商河 & 耕地、林地 & 有潜在污染源 & 淤泥 \\
\hline $\mathrm{J} 37$ & 大贺家铺 & 徒骇马项河区 & 大寺河 & 林地、耕地 & 明显 & 淤泥 \\
\hline $\mathrm{J} 38$ & 营子闸 & 徒骇马项河区 & 徒骇河 & 林地、耕地 & 明显 & 淤泥 \\
\hline J39 & 张公南临 & 徒骇马项河区 & 土马河 & 林地、耕地 & 明显 & 石块、淤泥、黏土 \\
\hline $\mathrm{J} 40$ & 刘家堡桥 & 徒骇马㚘河区 & 沙河 & 林地、耕地、住宅 & 有潜在污染源 & 淤泥 \\
\hline J41 & 周永闸 & 徒骇马㚘河区 & 商东河 & 林地、耕地 & 有潜在污染源 & 淤泥 \\
\hline $\mathrm{J} 42$ & 杆子行闸 & 徒骇马项河区 & 改碱河 & 耕地 & 明显 & 淤泥 \\
\hline $\mathrm{J} 43$ & 明辉路桥 & 徒骇马㚘页河区 & 商中河 & 住宅 & 有潜在污染源 & 淤泥、黏土 \\
\hline J44 & 潘庙闸 & 徒骇马项河区 & 临商河 & 林地、住宅 & 不明显 & 淤泥 \\
\hline $\mathrm{J} 45$ & 刘成桥 & 徒骇马项河区 & 徒骇河 & 林地、耕地 & 明显 & 石块、淤泥、黏土 \\
\hline
\end{tabular}

1.2.2 水环境理化因子测定 用便携式水质分析仪 YSI(Pro-plus) 现场测定气温 (Temp)、水温(W-Temp)、电 导率 ( Cond)、溶解氧 ( DO )、 $\mathrm{pH}$; 用直销塞氏盘 (黑白盘) 测定透明度 (Trans) ; 用米尺测定水深 (Depth)、河宽 (Wide) ; 用直读流速仪测定流速 (Velo).

用采水器采集 $2 \mathrm{~L}$ 水样, 低温保存, $48 \mathrm{~h}$ 内运送回实验室, 根据《地表水环境质量标准》GB 3838-2002 
测定浊度 $(\mathrm{Turb})$ 、钲离子 $\left(\mathrm{Ca}^{2+}\right)$ 、氯化物 $\left(\mathrm{Cl}^{-}\right)$、硫酸盐 $\left(\mathrm{SO}_{4}^{2-}\right)$ 、碳酸盐 $\left(\mathrm{CO}_{3}^{2-}\right)$ 、重碳酸盐 $\left(\mathrm{HCO}_{3}^{-}\right)$、总氮 $(\mathrm{TN})$ 、氨氮 $\left(\mathrm{NH}_{3}\right)$ 、亚硝酸盐 $\left(\mathrm{NO}_{2}^{-}\right)$、硝酸盐 $\left(\mathrm{NO}_{3}^{-}\right)$、化学需氧量 $(\mathrm{COD})$ 、生化需氧量 $(\mathrm{BOD}) 、$ 总磷 $(\mathrm{TP}) 、$ 总 碱度 $(\mathrm{Alk})$ 、总硬度 $(\mathrm{Hard})$ 和高锰酸盐指数 $\left(\mathrm{COD}_{\mathrm{Mn}}\right)$.

栖息地质量指数的获取采用现场打分法, 根据郑丙辉等 ${ }^{[39]}$ 构建的栖息地环境质量评价标准, 对栖息地 环境质量进行赋分.

\section{3 数据分析}

1.3.1 济南市各区域主要水环境因子分布特征 本研究共测定了 26 个水环境理化因子, 通过 Kolmogorov$\operatorname{Smirnov}(\mathrm{K}-\mathrm{S})$ 正态分布检验, 判断 26 个水环境因子是否符合正态分布. 结果显示, 多数水环境因子不符合正 态分布 $(P<0.05)$, 因而采用 Spearman 相关分析法对 26 个水环境因子进行相关性分析, 极显著相关的 2 个环 境因子只保留其中 1 个. 将篮选出的水环境因子进行小提琴图判别, 分析济南市不同区域水环境因子特征. K-S 分析和 Spearman 相关分析在 SPSS Statistics 17.0 中进行.

1.3 .2 济南市各区域水生生物丰富度与水环境因子响应分析 生态学中有两种常用的统计分析方法为圥余 分析 (Redundancy analysis, RDA) 和典范对应分析 (Canonical correspondence analysis, CCA), 用以分析生物群 落与环境因子的相互关系. 去趋势对应分析 (Detrended correspondence analysis, DCA) 是判别使用 RDA 或 CCA 的一种常用方法. 对生物数据进行 DCA 分析, 当排序轴的梯度值大于 4 时, 应选择 CCA 分析, 当排序轴 的梯度值小于 3 时, 应选择 RDA 分析, 当排序轴的梯度值介于 $3 \sim 4$ 之间时, 两种分析方法均可. 本研究对不 同区域水生生物丰富度指数进行 DCA 分析, 其梯度值均小于 3 , 因而选用 RDA 分析法分析各区域影响水生 生物群落的主要环境因子. DCA、RDA 和 CCA 分析使用 Canoco for windows 4.5 软件. 采用 Spearman 相关分 析法, 分析主要水环境因子与水生生物丰富度的相关性,并用 R 语言,绘制相关性矩阵图.

1.3 .3 济南市各区域水生生物丰富度分布特征 物种丰富度指数是一种简单、便捷并能较好指示物种丰富程 度的生物指数. 本研究计算了鱼类、底栖动物、浮游动物和浮游植物在每个采样点的物种丰富度, 根据 3 次 采样的结果, 取其平均值, 作为每个样点该物种的丰富度指数. 采用小提琴图法, 表征济南市不同区域水生 生物丰富度指数分布情况. 小提琴图是箱线图和核密度图的结合, 既可以展示分位数位置, 又可以展示每个 位置上的密度. 小提琴图采用 Python 软件绘制.

\section{2 结果}

\section{1 济南市各区域水生生物丰富度分布特征}

济南市黄河区共采集到鱼类 41 种、底栖动物 46 种、浮游动物 68 种、浮游植物 121 种, 其中个体数量最 多的优势物种分别为棒花鱼 (Abbottina rivularis)、喜盐摇蚊 (Chironomus salinarius)、矩形龟甲轮虫 (Keratella quadrata) 、小席藻 (Phormidium tenus). 城区共采集到鱼类 17 种、底栖动物 34 种、浮游动物 52 种、浮游植物 87 种, 个体数量最多的优势种分别为鲫(Carassius auratus)、葦氏白勃石蛭 (Barbronia weberi)、䓵花臂尾轮虫 (Brachionus calyciflorus)、小席藻. 小清河区共采集到鱼类 31 种、底栖动物 34 种、浮游动物 72 种、浮游植物 120 种, 个体数量最多的优势种分别为粲(Hemiculter leucisculus)、霍甫水丝蚓(Limnodrilus hoffmeisteri)、萼花 臂尾轮虫、小席藻. 徒骇马项河区共采集到鱼类 29 种、底栖动物 41 种、浮游动物 71 种、浮游植物 139 种, 个 体数量最多的优势种为鲫、霍甫水丝蚓、下氏晶囊轮虫 (Asplanchna brightwelli)、小颤藻 (Oscillatoria tenuis) (表 2).

小提琴图结果显示 (图 2), 黄河区、城区、小清河区、徒骇马㚘河区平均每个采样点采集到的鱼类种类数 分别为 4.4、2.4、1.8、3.3 种; 底栖动物分别为 $4.1 、 3.4 、 3.1 、 3.7$ 种; 浮游动物分别为 $3.5 、 2.8 、 4.1 、 5.1$ 种, 浮游植 物分别为 $12.0 、 10.7 、 10.9 、 12.2$ 种. 黄河区采集到的鱼类和底栖动物物种数最多, 徒骇马颊河区采集到的浮 游动物和浮游植物物种数最多, 小清河区采集到的鱼类和底栖动物物种数最少, 城区采集到的浮游动物和 浮游植物物种数最少. 
表 2 济南市各区域水生生物丰富度和优势种

Tab.2 The richness and dominant species at each ecoregion in Jinan City

\begin{tabular}{|c|c|c|c|c|c|}
\hline 水生生物 & & 黄河区 & 城区 & 小清河区 & 徒骇马㚘河区 \\
\hline \multirow[t]{2}{*}{ 鱼类 } & 丰富度 & 41 & 17 & 31 & 29 \\
\hline & 优势种 & 棒花鱼 & 鲫 & 粲 & 鲫 \\
\hline \multirow[t]{2}{*}{ 底栖动物 } & 丰富度 & 46 & 34 & 34 & 41 \\
\hline & 优势种 & 喜盐摇蚊 & 葦氏白勃石蛭 & 霍甫水丝蚓 & 霍甫水丝蚓 \\
\hline \multirow[t]{2}{*}{ 浮游动物 } & 丰富度 & 68 & 52 & 72 & 71 \\
\hline & 优势种 & 矩形龟甲轮虫 & 䓵花臂尾轮虫 & 䓵花臂尾轮虫 & 卜氏晶囊轮虫 \\
\hline \multirow[t]{2}{*}{ 浮游植物 } & 丰富度 & 121 & 87 & 120 & 139 \\
\hline & 优势种 & 小席藻 & 小席藻 & 小席藻 & 小颤藻 \\
\hline
\end{tabular}
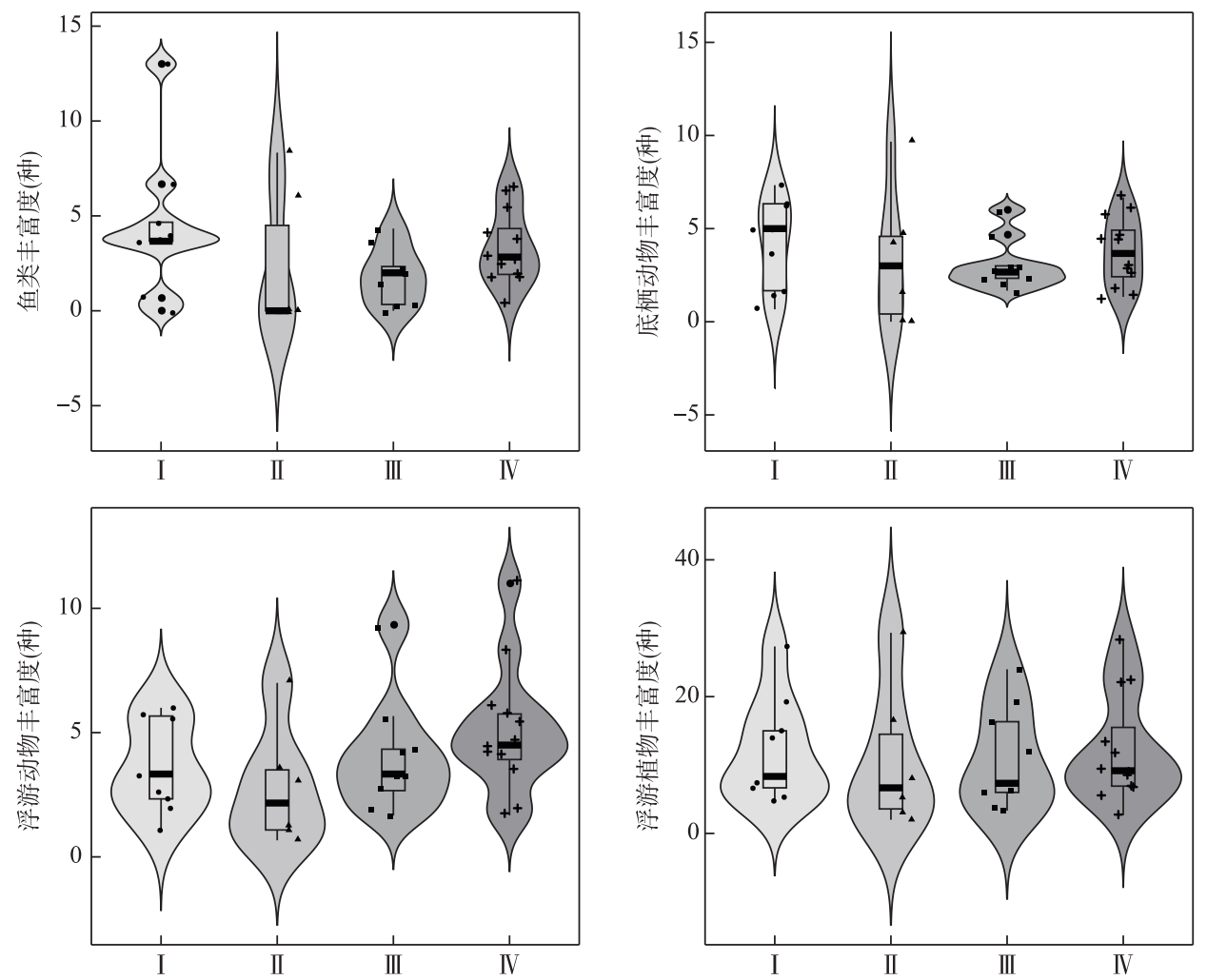

图 2 济南市各区域水生生物物种丰富度分布特征

Fig.2 Distribution of biological richness at each ecoregion in Jinan City

\section{2 济南市水环境因子特征分析}

Spearman 相关性分析结果显示 (图 3), Cond 与 $\mathrm{Ca}^{2+} 、 \mathrm{Cl}^{-} 、 \mathrm{SO}_{4}^{2-} 、 \mathrm{HCO}_{3}^{-} 、 \mathrm{Alk}$ 和 Hard 均呈极显著相关 (表 2), Cond 是以数字表示的溶液传导电流的能力, 在分析生物与环境因子的关系中应用广泛 ${ }^{[20]}$, 因此予以保 留. $\mathrm{CO}_{3}^{2-}$ 仅在 11 个点位有测量数据, 其他点位 $\mathrm{CO}_{3}^{2-}$ 含量极低, 可以忽略, 因而删除. $\mathrm{DO}$ 仅与 $\mathrm{NH}_{3}$ 和 $\mathrm{TP}$ 有较 强相关关系, 此外 DO 是衡量水体自净能力的一个较为重要的指标, 因此予以保留. $\mathrm{TN}$ 与 $\mathrm{pH} 、 \mathrm{NH}_{3} 、 \mathrm{NO}_{2}^{-}$、 $\mathrm{NO}_{3}^{-}$和 TP 均呈极显著相关, 而与 Cond、DO 和 COD 等无显著相关性, 因此予以保留. COD 与 Trans、Turb、 $\mathrm{COD}_{\mathrm{Mn}}$ 和 $\mathrm{BOD}$ 均呈极显著相关, 其中 $\mathrm{COD} 、 \mathrm{COD}_{\mathrm{Mn}}$ 和 $\mathrm{BOD}$ 均可反映水体中有机污染状况, 因而随机保留了 
COD 来反映水体有机污染程度. Flow 等于 Velo、Wide 和 Depth 的乘积, 三者相关关系十分密切, 而 Flow 是一 种常用的水文参数, 常用来分析其与生物之间的关系 ${ }^{[40]}$, 因此予以保留. Temp 和 W-Temp 受外界环境影响 较大, 且与每次的采样时间有较大关系, 数据不太稳定, 予以删除. 因此, 共篮选出 Cond、COD、Flow、DO、TN、 QHEI 六个水环境因子,其在各区域的分布特征如图 4 所示.

QHEI 在黄河区、城区、小清河区、徒骇马颊河区的平均值分别为 $108.4 、 94.67 、 68.56 、 87.67$,黄河区栖息 地质量较好, 城区虽然平均值较高, 但值域范围较大; Flow 在黄河区、城区、小清河区、徒骇马颊河区的平均 值分别为 $239.1 、 2.84 、 4.74 、 0.27 \mathrm{~m}^{3} / \mathrm{s}$, 黄河区有 3 个采样点位于黄河干流, 使黄河区的流量平均值明显高于 其他 3 个区域; DO 在黄河区、城区、小清河区、徒骇马颊河区的平均值分别为 $7.89 、 7.11 、 7.55 、 8.14 \mathrm{mg} / \mathrm{L}, 4$ 个区域 DO 平均值相差不大; Cond 在黄河区、城区、小清河区、徒骇马颊河区的平均值分别为 856.6、731.82、 $1396.84 、 1860.14 \mathrm{mS} / \mathrm{m}$, 徒骇马颊河区电导率最大, 城区电导率值最小; COD 在黄河区、城区、小清河区、徒骇 马颊河区的平均值分别为 $20.76 、 33.84 、 29.19 、 34.31 \mathrm{mg} / \mathrm{L}$, 黄河区 COD 平均值最低, 其余 3 个区域 COD 平 均值相差不大; TN 在黄河区、城区、小清河区、徒骇马颊河区的平均值分别为 $3.91 、 5.66 、 7.45 、 3.61 \mathrm{mg} / \mathrm{L}$, 徒 骇马㚘河区 TN 浓度最低,小清河区 TN 浓度最高(图4).

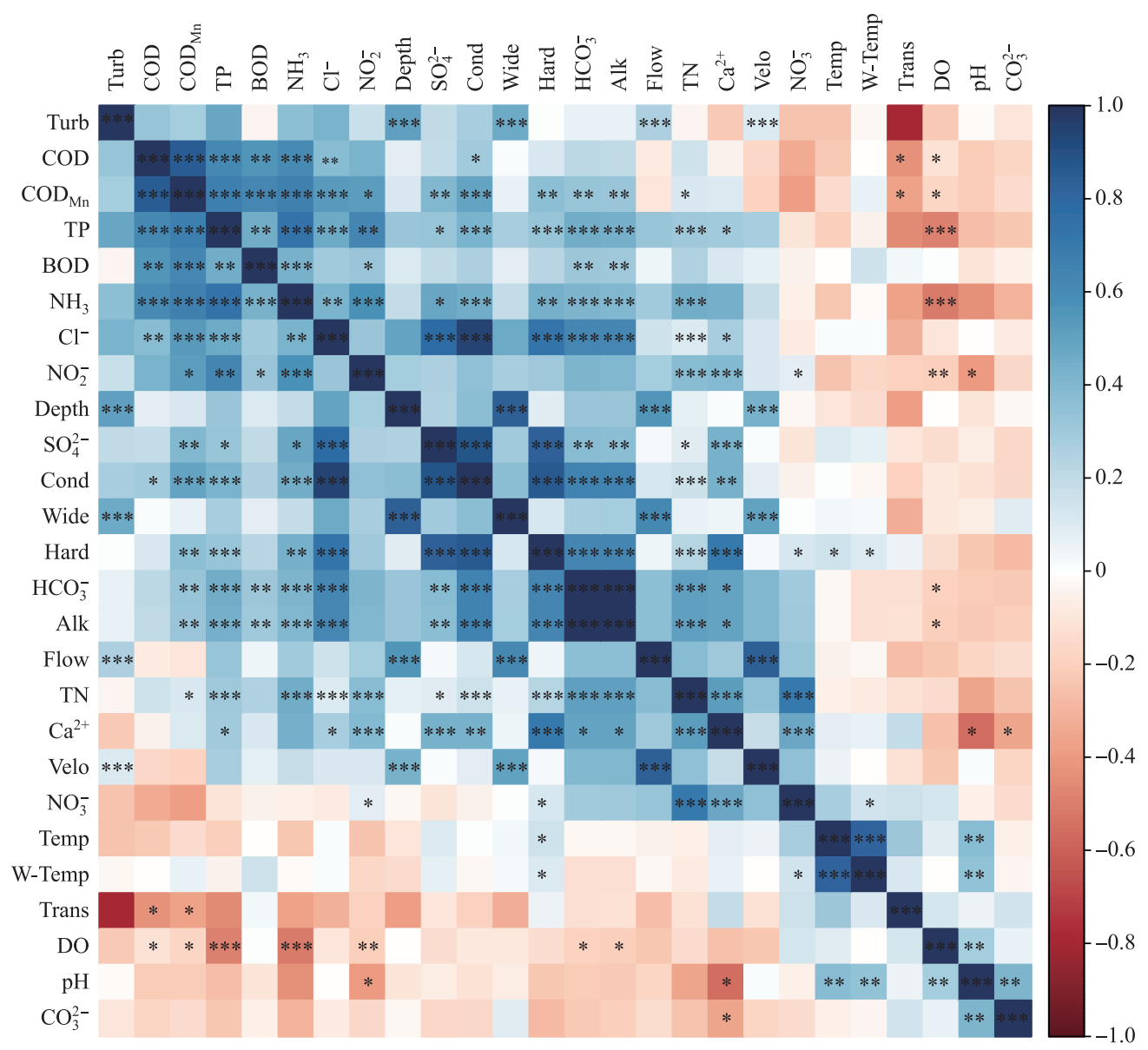

图 3 济南市水环境因子 Spearman 相关矩阵图 $(* P<0.05, * * P<0.01, * * * P<0.001)$

Fig.3 The Spearman correlation matrix of physio-chemical factors in Jinan City $(* P<0.05, * * P<0.01, * * * P<0.001)$ 

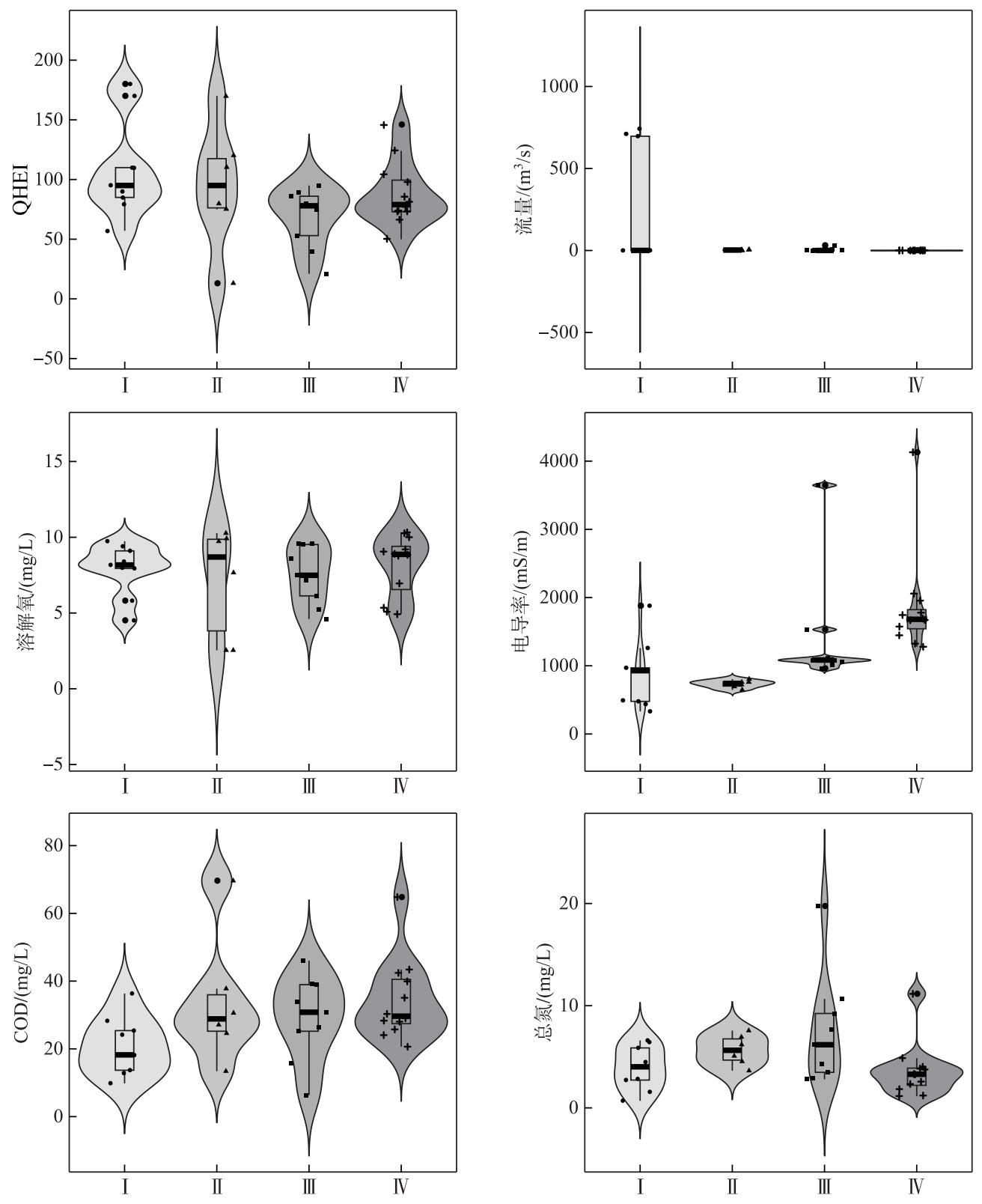

图 4 济南市主要水环境因子在各区域的分布

Fig.4 Distribution of main physio-chemical factors at each ecoregion in Jinan City

\section{3 济南市水生生物丰富度与水环境因子的响应关系}

冗余分析结果表明 (表 3), 黄河区和城区水生生物丰度与水环境因子关系不显著, 小清河区影响水生生 物丰度的主要环境因子为 $\operatorname{COD}(P=0.015) 、 \operatorname{DO}(P=0.02)$ 和 $\operatorname{QHEI}(P=0.032)$. 徒骇马颊河区影响水生生物 丰度的主要环境因子为 $\mathrm{TN}(P=0.04)$. Spearman 结果显示, Cond 与黄河区鱼类丰富度呈显著负相关 $(P<$ $0.05)$, 相关系数为 $-0.80, \mathrm{TN}$ 浓度与城区底栖动物丰富度、小清河区鱼类丰富度显著负相关, 相关系数分别 为 -0.90 和 $-0.67(P<0.05), \mathrm{COD}$ 与小清河区浮游动物丰富度呈显著相关, 相关系数为 $0.79(P<0.05)$ ( 图 5). 
表 3 济南市各区域水生生物丰富度与水环境因子先余分析的统计值

Tab.3 Statistics of RDA between biological richness and physio-chemical factors at each ecoregion in Jinan City

\begin{tabular}{|c|c|c|c|c|c|c|c|c|}
\hline \multirow{2}{*}{ 水环境因子 } & \multicolumn{2}{|c|}{ 黄河区 } & \multicolumn{2}{|c|}{ 城区 } & \multicolumn{2}{|c|}{ 小清河区 } & \multicolumn{2}{|c|}{ 徒骇马㚘河区 } \\
\hline & $F$ & $P$ & $F$ & $P$ & $F$ & $P$ & $F$ & $P$ \\
\hline QHEI & 0.52 & 0.677 & - & - & 5.98 & $0.032 *$ & 0.25 & 0.901 \\
\hline Flow & 0.97 & 0.407 & 36.17 & 0.068 & 2.82 & 0.176 & 0.78 & 0.513 \\
\hline Cond & 3.10 & 0.099 & 1.11 & 0.363 & 2.87 & 0.109 & 1.35 & 0.280 \\
\hline DO & 0.97 & 0.501 & 1.31 & 0.360 & 5.02 & $0.020^{*}$ & 0.31 & 0.850 \\
\hline COD & 1.74 & 0.227 & 0.00 & 1.000 & 4.22 & $0.015^{*}$ & 1.78 & 0.169 \\
\hline $\mathrm{TN}$ & 1.25 & 0.309 & 0.61 & 0.520 & 0.52 & 0.639 & 4.36 & 0.040 * \\
\hline
\end{tabular}

*表示 $P<0.05$.

\section{3 讨论}

济南市作为以行政区划为边界的城市水体类型, 水生态系统的健康与否与人类活动的扰动强弱具有密 切的相关性. 根据济南统计局数据显示, 2013 年济南南部黄河区人口数量为 92.7 万, 城区为 205.9 万, 小清 河区为 195.7 万, 徒骇马颊河区为 118.85 万, 从济南市人口数量分布可以看出, 黄河区人口数量在全市范围 内最低, 主要原因在于黄河区位于济南南部山区, 植被森林覆盖率较高, 人类对山区的开发程度相对较低, 对水生态的影响相对较小, 水生生物的物种丰富度相对较高. 杜龙飞等 ${ }^{[41]}$ 对北京市主要河流展开调查, 发 现上游山区鱼类多样性明显高于下游平原区. 渠晓东等 ${ }^{[42]}$ 研究太子河流域时发现, 上游山地区底栖动物的 多样性指数值最高. 本研究结果表明, 黄河区鱼类和底栖动物丰富度明显高于其他区域, 这一结果与两位学 者的研究相一致. 表明在一个流域中, 上游山区水体水生生物的多样性要高于下游平原区. 水环境质量分析 结果也表明, 黄河区 COD、TN、Cond 在全流域均较低. 张殷俊等 ${ }^{[43]}$ 表示, 在垂直河道 $500 \mathrm{~m}$ 以上范围内的缓 冲区, 林地面积对改善水质, 特别对氮、磷营养元素的削减具有显著作用. 黄河区浮游植物丰富度相对较低, 但桥弯藻、曲壳藻等在黄河区的物种数较多,这些藻类通常表征水质较为清洁 ${ }^{[44]}$. Pardo 等 ${ }^{[45]}$ 对西班牙北部 河流硅藻群落进行了划分, 发现极细曲壳藻 (Achnanthidium minutissimum) 在山区河流中是主要的优势种, Delgado 等 ${ }^{[46]}$ 表示, 当水体中磷酸盐浓度高于 $0.3 \mathrm{mg} / \mathrm{L}$ 时, 不适宜极细曲壳藻生存. 城区、小清河区和徒骇 马项河区, 这些藻类几乎没有. 小清河区和徒骇马颊河区属于平原区, 人类开发程度较高, 土地利用主要以 农田为主. 根据相关文献, 1980s 小清河是纳受济南市污水的唯一水体 ${ }^{[47]}$, 六大排污系统近 20 条河沟及排 污管道汇人小清河, 使小清河水质遭受严重破坏 ${ }^{[48]}$. 本研究结果显示, 小清河 TN 浓度最高, 水生生物丰富 度值最低.

穴余分析图中显示 (图 6), 水生生物丰富度指数与环境因子之间夹角的余弦值表征两个参数的相关性 系数, 当夹角小于 $90^{\circ}$ 时, 夹角越小余弦值越大, 两个参数的相关性越强, 且为正相关; 当夹角大于 $90^{\circ}$ 时, 夹 角越大余弦值的绝对值越大, 两个参数的相关性越强, 并为负相关. Spearman 结果显示, 黄河区电导率与鱼 类丰富度呈负相关关系, RDA 图中两个参数的指示线基本呈一条直线, 余弦值在 -0.99 以上, 表明电导率对 黄河区鱼类丰富度均有显著影响. 李丽娟等 ${ }^{[49]}$ 在研究太子河流域鱼类群落结构特征时发现, 电导率对产浮 性卵鱼类群落具有显著相关性. 刘猛等 ${ }^{[50]}$ 研究发现, 电导率对浑太河流域鱼类群落结构的完整性具有显著 的影响. 城区 TN 平均浓度在 4 个研究区中排列第二, 远超过国家规定的 $\mathrm{V}$ 类水标准. RDA 图和 Spearman 分 析结果显示, TN 浓度与城区底栖动物丰富度呈显著负相关. 赵风斌等 ${ }^{[51]}$ 在研究上海市河流底栖动物群落结 构与水环境质量关系时发现, TN、DO、 $\mathrm{pH}$ 、盐度对底栖动物种类影响最大, 其中霍甫水丝蚂与 $\mathrm{TP} 、 \mathrm{TN} 、 \mathrm{COD}_{\mathrm{Mn}}$ 相关性最大, 是重度富营养化的指示种, 这一结果与本研究结果较为一致. Spearman 和 RDA 结果显示, 小清 河区 TN 对鱼类丰富度影响最大, 两轴几乎成一条直线, 相关性数值在 -0.99 以上. 小清河区水体主要功能 为泄洪、排涝、通航、灌溉和排污等, 其中排污是小清河一项重要水体功能, 在采样过程中发现, 靠近城区的 


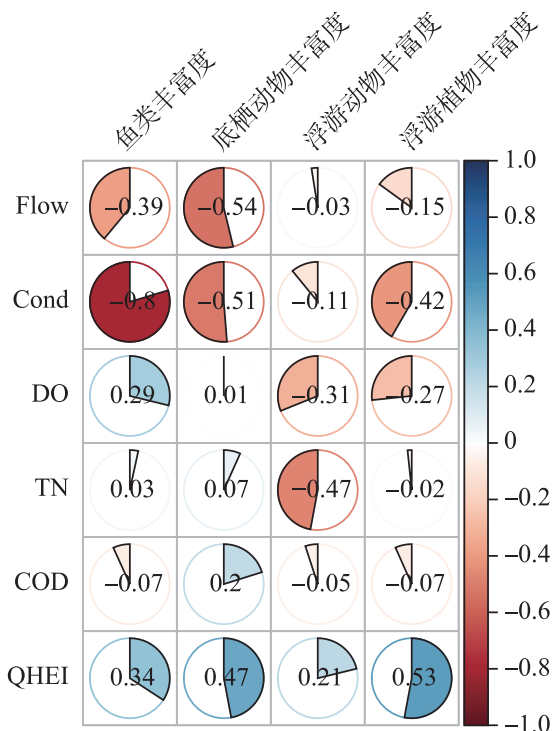

(a) 黄河区

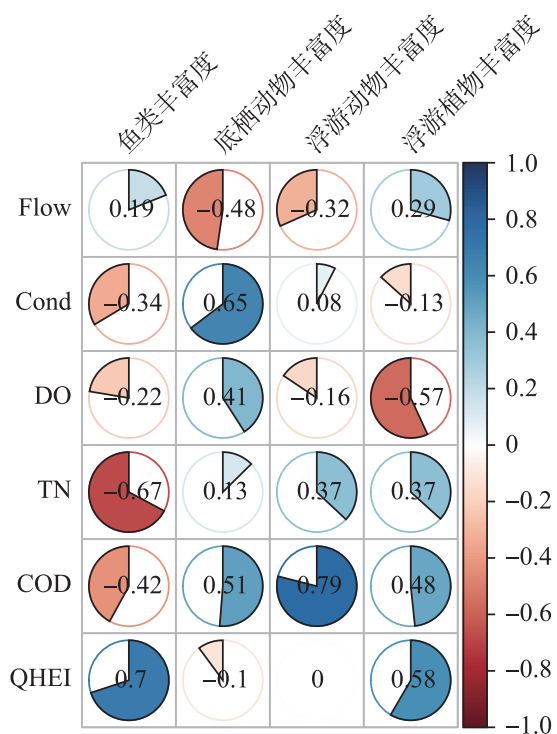

(c) 小清河区

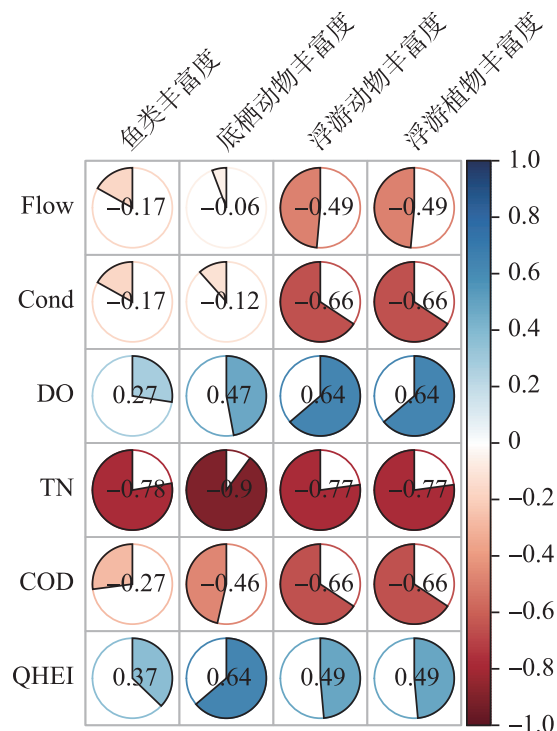

(b) 城区

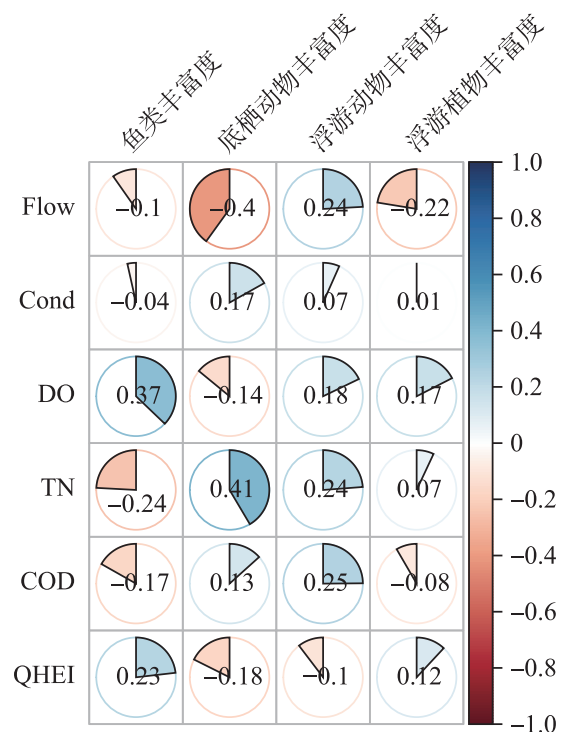

(d) 徒骇马颊河区

图 5 济南市各区域水生生物丰富度与主要水环境因子相关矩阵图

Fig.5 The correlation matrix between biological richness and the main physio-chemical factors at each ecoregion in Jinan City

点位, 河道均有排污口, 这些均造成小清河水质较差, 富营养化严重, 对鱼类丰富度影响较大. 石睿杰等 ${ }^{[22]}$ 通过多元线性回归法分析了长江流域鱼类多样性与环境因子的响应关系, 发现长江中下游鱼类多样性与 $\mathrm{TN}$ 浓度存在正向相关关系, 其原因可能由于 $\mathrm{TN}$ 浓度没有达到特定阈值, 且氮元素在鱼类繁殖代谢等生理 过程中具有正向作用, 这一结果与本研究结果相悖. 对比发现, 长江流域中下游 TN 浓度在 $1.8 \mathrm{mg} / \mathrm{L}$ 左右, 而济南小清河流域 TN 浓度高达 $7.45 \mathrm{mg} / \mathrm{L}$, 远远高于长江水体中 TN 浓度, 这可能是造成研究结果存在差异 的主要原因. 徒骇马项河区, TN 是影响水生生物丰度的主要环境因子, 其中对鱼类的影响最为显著. 在采样 过程中发现, 北田家 (J33) 点位 TN 浓度较高, 但河道中设有大量渔网, 限制了鱼类的活动空间, 而大贺家铺 
(J37) 和张公南临 (J39) 两个点位, 虽河流栖息地质量较高, 但 $\mathrm{TN}$ 浓度较高, 且河水流量较小, 大贺家铺在采 样点河段出现多处断流,这些均造成鱼类丰度较低,使其与 TN 浓度呈负相关关系.
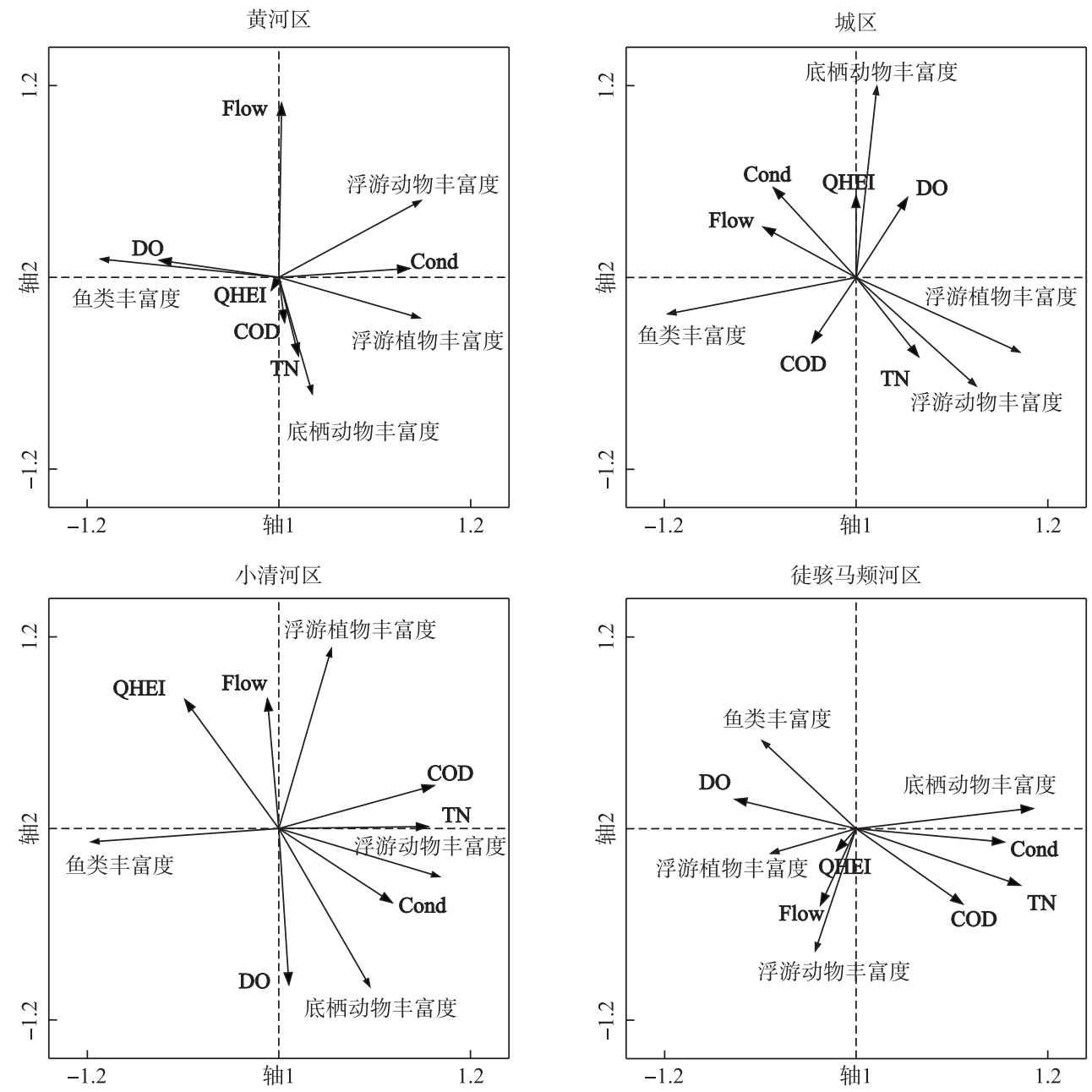

图 6 济南市各区域水生生物丰富度指数与水环境因子攵余分析图

Fig. 6 The graph of RDA between biological richness and physiochemical factors at each ecoregion in Jinan City

根据本研究的分析结果, 济南市黄河区水生态总体状况较好, 水生生物丰度和水质较高, 城区西部水生 生物丰富度优于城区东部, 小清河区水生生物丰富度和水环境质量最差, 徒骇马规河区为一般水平. 因此, 在制定济南市水生态系统修复保护计划时, 可加强南部黄河区水生态系统的保护,使其受人类活动影响程 度最低; 加强对小清河区水质净化与污水排放的监管力度,减免黑臭水体的存在;徒骇马颊河区面源污染较 为严重, 可建立相应的生态保护区或人工湿地, 降低人类活动造成的影响. 此外,除城区外,其余三区鱼类的 丰富度指数与水环境因子均具有较显著的相关性, 在未来水环境监测中, 可以考虑将鱼类作为长期监测的 指示生物, 用以监管和评价济南市水生态修复的成效. 本研究虽以济南市为研究区, 但为其他城市水生态文 明建设提供了一种分析思路. 水生生物与水环境因子响应关系错综复杂, 本研究主要分析了水生生物丰富 度指数与水环境因子的响应关系, 并未考虑水生生物其他生物参数, 如多样性指数、耐污性指数、敏感性指 数、功能群等对水环境因子的响应关系, 在未来研究中, 可以增加生物参数指标, 以便更为全面准确地反映 水生生物与水环境因子的相关关系. 


\section{4 结论}

1) 济南市鱼类和底栖动物丰富度在各区域的分布特征为:黄河区 $>$ 徒骇马颊河区 $>$ 城区 $>$ 小清河区; 浮游 动物丰富度在各区分布特征为: 徒骇马项河区 $>$ 小清河区 $>$ 黄河区 $>$ 城区; 浮游植物丰富度在各区的分布为: 徒骇马项河区>黄河区 >小清河区>城区. 黄河区水生生物丰富度较高, 小清河区和城区水生生物丰富度 最低.

2) 通过 Spearman 相关分析笁选出 Flow、Cond、DO、TN、COD 和 QHEI 六个水环境因子. 其中, 黄河区 QHEI、Flow、DO 值较高, COD、Cond、TN 浓度较低; 小清河区 TN 浓度最高, 徒骇马项河区 COD 和 Cond 值 最高.

3 ) 黄河区鱼类丰富度与 Cond 呈显著负相关; 城区底栖动物丰富度与 TN 浓度呈显著负相关; 影响小清 河区水生生物丰富度的主要环境因子为 COD、DO 和 QHEI, 影响徒骇马项河区水生生物丰富度的主要环境 因子为 TN.

致谢: 感谢山东省水利科学研究院、济南市水文局和大连海洋大学相关科研人员在野外采样调查和数据处 理中给予的帮助.

\section{5 参考文献}

[ 1 ] Yin K, Wang YY. Research on assessment system of national river basin water eco-environmental quality. Environmental Monitoring in China, 2018, (1) : 1-8. [阴琨, 王业耀. 水生态环境质量评价体系研究. 中国环境监测, 2018, (1): 1-8. ]

[ 2 ] Adam MS, Hifney AF, Fawzy MA et al. Seasonal biodiversity and ecological studies on the epiphytic microalgae communities in polluted and unpolluted aquatic ecosystem at Assiut, Egypt. European Journal of Ecology, 2017, 3(2) : 92-106.

[ 3 ] Zhang L, Wei C, Zhang H et al. Criteria for assessing the ecological risk of nonylphenol for aquatic life in Chinese surface fresh water. Chemosphere, 2017, 184: 569-574.

[ 4 ] Park T, Lee J, Lee M et al. Development of water quality criteria of ammonia for protecting aquatic life in freshwater using species sensitivity distribution method. Science of the Total Environment, 2018, 634: 934-940.

[ 5 ] Prabhakaran K, Nagarajan R, Merlin FF et al. Biomonitoring of Malaysian aquatic environments: A review of status and prospects. Ecohydrology \& Hydrobiology, 2017, 17(2) : 134-147.

[ 6 ] Gao H, Qian X, Wu H et al. Combined effects of submerged macrophytes and aquatic animals on the restoration of a eutrophic water body - A case study of Gonghu Bay, Lake Taihu. Ecological Engineering, 2017, 102: 15-23.

[ 7 ] $\mathrm{Wu} \mathrm{W}, \mathrm{Xu} \mathrm{Z}$, Kennard MJ et al. Do human disturbance variables influence more on fish community structure and function than natural variables in the Wei River basin, China? Ecological Indicators, 2016, 61: 438-446.

[ 8 ] Wu W, Xu Z, Yin X et al. Assessment of ecosystem health based on fish assemblages in the Wei River basin, China. Environmental Monitoring and Assessment, 2014, 186(6) : 3701-3716.

[ 9 ] Huang Q, Gao J, Cai Y et al. Development and application of benthic macroinvertebrate-based multimetric indices for the assessment of streams and rivers in the Taihu Basin, China. Ecological Indicators, 2015, 48: 649-659.

[10] Li Y, Li Y, Xu Z et al. Assessment of the Huntai River in China using a multimetric index based on fish and macroinvertebrate assemblages. Journal of Freshwater Ecology, 2016, 31(2) : 1-22.

[11] Mangadze T, Bere T, Mwedzi T. Choice of biota in stream assessment and monitoring programs in tropical streams: A comparison of diatoms, macroinvertebrates and fish. Ecological Indicators, 2016, 63: 128-143.

[12] Muhid P, Davis TW, Bunn SE et al. Effects of inorganic nutrients in recycled water on freshwater phytoplankton biomass and composition. Water Research, 2013, 47 (1) : 384-394.

[13] Carpenter KE, Johnson JM, Buchanan C. An index of biotic integrity based on the summer polyhaline zooplankton community of the Chesapeake Bay. Marine Environmental Research, 2006, 62(3) : 165-180.

[14] Yang Y, Ni P, Gao Y et al. Geographical distribution of zooplankton biodiversity in highly polluted running water ecosystems: Validation of fine-scale species sorting hypothesis. Ecology and Evolution, 2018, 8(10) : 4830-4840.

[15] Kimmel WG, Argent DG. Community concordance between fishes and benthic macroinvertebrates among adventitious and 
ordinate tributaries of a major river system. Ecological Indicators, 2016, 70: 15-22.

[16] Zhao C, Yang S, Liu J et al. Linking fish tolerance to water quality criteria for the assessment of environmental flows: A practical method for streamflow regulation and pollution control. Water Research, 2018, 141: 96-108.

[17] Wang XN, Peng SX, Zhang Y et al. Analysis of fish community spatial heterogeneity and its driving factors in the Luanhe River Basin. Research of Environmental Sciences, 2018, (2) : 273-282. [王晓宁, 彭世贤, 张亚等. 滦河流域鱼类群落 结构空间异质性与影响因子分析. 环境科学研究, 2018, (2) : 273-282.]

[18] Serrano EC, Grac C, Berti EL et al. Potential application of macroinvertebrates indices in bioassessment of Mexican streams. Ecological Indicators, 2016, 61: 558-567.

[19] Wang L, Yang HJ, Li K et al. Seasonal dynamics of macroinvertebrate community structure in a headwater stream in the Changbai Mountains. Acta Ecologica Sinica, 2018, 38(13): 4834-4842. [王璐, 杨海军, 李昆等. 长白山源头溪流底 栖动物群落结构季节动态. 生态学报, 2018, 38(13): 4834-4842.]

[20] Yin XW, Qu XD, Li QN et al. Using periphyton assemblages to assess stream conditions of Taizi River Basin, China. Acta Ecologica Sinica, 2012, 32(6): 1677-1691. [殷旭旺, 渠晓东, 李庆南等. 基于着生藻类的太子河流域水生态系统 健康评价. 生态学报, 2012, 32(6): 1677-1691.]

[21] Cai K, Qin CY, Li JY et al. Preliminary study on phytoplanktonic index of biotic integrity ( P-IBI) assessment for lake ecosystem health: a case of Taihu Lake in Winter, 2012. Acta Ecologica Sinica, 2016, 36(5) : 1431-1441. [蔡琨, 秦春 燕, 李继影等. 基于浮游植物生物完整性指数的湖泊生态系统评价一以 2012 年冬季太湖为例. 生态学报, 2016, 36(5) : 1431-1441.]

[22] Liu PP, Wang L, Wang P et al. The characteristics of zooplankton community and water quality in the Shaying River basin. Acta Hydrobiologica Sinica, 2018, (2):373-381. [刘盼盼, 王龙, 王培等. 沙颖河流域浮游动物群落结构空间 变化特征与水质评价. 水生生物学报, 2018, (2) : 373-381.]

[23] Wu L, Li YL, Chen YS. Characteristics of community structures of zooplankton in the mainstream of Huaihe River. J Lake $S c i, 2015,27$ (5) : 932-940. DOI: 10.18307/2015.0521. [ 吴利, 李源玲, 陈延松. 淮河干流浮游动物群落结构特征. 湖泊科学, 2015, 27(5): 932-940.]

[24] Zhao CS, Yang ST, Xiang H et al. Hydrologic and water-quality rehabilitation of environments for suitable fish habitat. Journal of Hydrology, 2015, 530: 799-814.

[25] Zhang W, Zhang X, Li L et al. Urban forest in Jinan City: Distribution, classification and ecological significance. Catena, $2007,69(1): 44-50$.

[26] Yu S, Xu Z, Liu X et al. Identifying and validating freshwater ecoregions in Jinan City, China. Journal of Hydrology, 2015, 528: 763-772.

[27] Cheng QT ed. The fishes of Shandong province. Jinan: Shandong Science and Technology Press, 1997. [成庆泰. 山东鱼 类志. 济南: 山东科学技术出版社, 1997.]

[28] Chen YY ed. Fauna Sinica: Osteichthyes Cypriniformes II. Beijing: Science Press, 1998. [陈宜瑜. 中国动物志: 硬骨 鱼纲鲤形目 (中卷). 北京: 科学出版社, 1998.]

[29] Le PQ ed. Fauna Sinica: Osteichthyes Cypriniformes III. Beijing: Science Press, 2000. [乐佩琪. 中国动物志: 硬骨鱼 纲鲤形目 (下卷). 北京: 科学出版社, 2000.]

[30] Wang JC, Wang XH eds. Chironomus larvae in northern China. Beijing: China Yan Shi Press, 2011. [王俊才, 王新华. 中国北方摇蚊幼虫. 北京: 中国言实出版社, 2011.]

[31] Yang T ed. Fauna Sinica: Annelida, Hirudinea. Beijing: Science Press, 2002. [杨潼. 中国动物志 环节动物门 蛭纲. 北京: 科学出版社, 2002.]

[32] Lin GY ed. Fauna Sinica: Phylum Mollusca, Class Gastropoda, Subclass Opisthobranchia, Order Cephalaspidea. Beijing: Science Press, 1997. [林光宇. 中国动物志 软体动物门 腹足纲 后鳃亚纲 头楯目. 北京: 科学出版社, 1997.]

[33] Han MS, Dong YF eds. The freshwater biograph of China. Beijing: Ocean Press, 1995. [ 韩茂森, 东蕴芳. 中国淡水生物 图谱. 北京: 海洋出版社, 1995.]

[34] Jiang XZ ed. Fauna Sinica: Phylum Arthropoda, Class Crustacea, Freshwater cladocera. Beijing: Science Press, 1979. [蒋隻治. 中国动物志 节肢动物门甲壳纲 淡水枝角类. 北京: 科学出版社, 1979.]

[35] Crustacean research group, Institute of Zoology, Chinese Academy of Sciences ed. Fauna Sinica: Phylum Arthropoda, Class Crustacea, hydrocopepoda. Beijing: Science Press, 1979. [中国科学院动物研究所甲壳动物研究组编著. 中国 
动物志 节肢动物门甲壳纲 淡水桡足类. 北京: 科学出版社, 1979.]

[36] Wand JJ ed. The freshwater rotifers of China. Beijing: Science Press, 1961. [王家楫. 中国淡水轮虫志. 北京: 科学出 版社, 1961.]

[37] Weng JZ, Xu HS eds. The common freshwater phytoplankton in China. Shanghai: Shanghai Science and Technology Press, 2010. [ 翁建忠, 徐恒省. 中国常见淡水浮游藻类图谱. 上海: 上海科学技术出版社, 2010.]

[38] Hu HJ, Wei YX eds. The freshwater algae of China: Systematics, taxonomy and ecology. Beijing: Science Press, 2006. [胡鸿钧, 魏印心. 中国淡水藻类——系统、分类及生态. 北京: 科学出版社, 2006.]

[39] Zheng BH, Zhang Y, Li YB. Study of indicators and methods for river habitat assessment of Liao River Basin. Acta Scientiae Circumstantiae, 2007, (6) : 928-936. [郑丙辉, 张远, 李英博. 辽河流域河流栖息地评价指标与评价方法研究. 环境科学学报, 2007, (6): 928-936.]

[40] Yin XW, Li QN, Zhu MH et al. Community structure and biological integrity of macroinvertebrates in the wet and dry seasons of Wei River basin, China. Acta Ecologica Sinica, 2015, 35(14)：4784-4796. [殷旭旺, 李庆南, 朱美桦等. 渭 河丰、枯水期底栖动物群落特征及综合健康评价. 生态学报, 2015, 35(14) : 4784-4796.]

[41] Du LF, Xu JX, Li YB et al. Fish community characteristics and spatial pattern in major rivers of Beijing metropolitan. Research of Environmental Sciences, 2019, 32(3): 447-457. [杜龙飞, 徐建新, 李彦涁等. 北京市主要河流鱼类群落的 空间格局特征. 环境科学研究, 2019, 32(3): 447-457.]

[42] Qu XD, Zhang Y, Ma SQ et al. Spatial distribution characteristics of macroinvertebrate communities in Taizi River basin. Research of Environmental Sciences, 2013, 26(5) : 509-515. [ 渠晓东, 张远, 马淑芹等. 太子河流域大型底栖动物群 落结构空间分布特征. 环境科学研究, 2013, 26(5) : 509-515.]

[43] Zhang YJ, Chen S, Xiang JC. Correlation between the water quality and land use composition in the river side area. Resources an Environment in the Yangtze Basin, 2011, (9): 1054-1061. [张殷俊, 陈爽, 相景昌. 河流近域土地利用格 局与水质相关性分析一以巢湖流域为例. 长江流域资源与环境, 2011，(9): 1054-1061.]

[44] Deng DY, Lu W, Tao M. Recent advances and indicative role of diatom s in water environment monitoring. Environmental Science \& Technology, 2009, (B12) : 222-225. [邓迪勇, 卢伟, 陶敏. 硅藻在水环境监测中的指示作用及研究进展. 环境科学与技术, 2009, (B12): 222-225.]

[45] Pardo I, Delgado C, Abraín R et al. A predictive diatom-based model to assess the ecological status of streams and rivers of Northern Spain. Ecological Indicators, 2018, 90: 519-528.

[46] Delgado C, Pardo I. Comparison of benthic diatoms from Mediterranean and Atlantic Spanish streams: Community changes in relation to environmental factors. Aquatic Botany, 2015, 120: 304-314.

[47] Sun YL, Lu MS, Wang GH. The research of pollution control approach of Xiaoqing River, in Jinan. Environmental Science, 1984, (6) : 37-40. [孙玉琳, 陆惁荪, 王光和. 小清河济南段污染防治途径的研究. 环境科学, 1984, (6) : 37-40.]

[48 ] Ma JG, Guo HX, Mei ZB et al. Reasons of water pollution and management of Xiaoqing River in Shandong province. China Rural Water and Hydropower, 2003, (8): 53-54. [马吉刚, 郭红欣, 梅泽本等. 山东小清河水质污染原因及治理对 策分析. 中国农村水利水电, 2003, (8): 53-54.]

[49] Li LJ, Zhang J, Wu D et al. Relationships between structure and diversity of fish functional groups and land use in the Taizi River. Acta Ecologica Sinica, 2017, 37(20): 1-11. [李丽娟, 张吉, 吴丹等. 太子河流域鱼类功能群结构与多样 性对土地利用类型的响应关系. 生态学报, 2017, 37(20): 1-11.]

[50] Liu M, Qu XD, Peng WQ et al. Development and application of a fish-based index of biological integrity for the Hun-Tai River Basin. Research of Environmental Sciences, 2016, 29(3): 343-352. [刘猛, 渠晓东, 彭文启等. 浑太河流域鱼类 生物完整性指数构建与应用. 环境科学研究, 2016, 29(3): 343-352.]

[51] Zhao FB, Chen PP, Xu HT et al. The community structure and their relationships of zoobenthos with environmental factors in Shanghai urban rivers. Ecology and Environmental Sciences, 2016, 25(8): 1361-1368. [赵风斌, 陈萍萍, 徐后涛等. 上海市河道底栖动物群落结构与环境因子的关系. 生态环境学报, 2016, 25(8)：1361-1368.]

[52] Shi RJ, Tang LH, Gao GD et al. Analysis on the relationship between fish diversity and watershed features in the Yangtze Rive Basin. J Tsinghua Univ: Sci \& Technol, 2018, 58(7) : 650-657. [石睿杰, 唐莉华, 高广东等. 长江流域鱼类多 样性与流域特性关系分析. 清华大学学报: 自然科学版, 2018, 58(7): 650-657.] 